\title{
Through the Stomach to the Heart
}

\author{
Practices of Kinship of Families of Choice in Poland
}

\begin{abstract}
The concept of families of choice was introduced almost three decades ago by Kath Weston (1997). She used it to describe the situation of the LGBTQ community in the era of the HIV/AIDS crisis, when the relations with families of origin had been heavily tested and proved to fail, whereas relations with friends were the primary source of care and support for the sick and dying, as well as their partners. Since then, contemporary non-heterosexual families are understood as their queer descendants and often the term "families of choice" is used synonymously. However, whereas much had been written about the ideologies of queer kinship, the sphere of the daily, ordinary, and often imperceptible practices of kinning, when nothing exceptional is happening (like a disease or family crisis) has still not been sufficiently examined. Therefore, it could be argued that the debate on queer kinship is rather conceptual and abstract with its focus on normativity/antinormativity (Wiegman and Wilson 2015), whereas the sphere of ordinariness and everydayness, where most of the queer kinning actually happens, is being neglected and marginalised in the discussion on queer kinship.

In the paper, we explore this unmapped territory of queer kinship studies and specifically take a closer look at the material and everyday dimensions of kinship. To do so, we use the data gathered within the ethnographic research done within the Families of Choice in Poland-study (2013-20I6, PI: Joanna Mizielińska). In this project, during thirty days of observation and several thematic interviews, done with twenty-one families, we were able to capture an in-depth picture of how the kinning practices are performed in daily life. In the paper we explore
\end{abstract}


practices of silent intimacy (Jamieson 1998), focusing on food sharing practices among partners, but also between them and their families of origin that not always fully accept and support their relationship. In critical dialogue with AngloAmerican scholarship on queer kinship, which built on and extends Weston's classic work, we want to demonstrate that changing focus from its antinormative centrality towards embracing the ordinariness (Martin 1997) and everydayness of queer kinning, might not only contribute to developing the field, but also help us to understand the complexity of relational lives.

Keywords: food practices, families of choice, queer kinship, queer intimacies, families of origin

THE CONCEPT OF families of choice was introduced almost three decades ago by Kath Weston (1997). She used it to describe the situation of the LGBTQ community in the era of the HIV/AIDS crisis, when the relations with families of origin were heavily tested and proved to fail, whereas relations with friends and partners (current and former) were the primary source of care and support for the sick and dying, as well as their loved ones. Since then, contemporary non-heterosexual families have come to be seen as their queer descendants, and the term "families of choice" is often used synonymously. However, whereas much has been written about the ideologies of queer kinship, the sphere of the daily, ordinary, and often imperceptible practices of kinning, when nothing exceptional happens (such as a disease or family crisis) has not been sufficiently examined yet. Therefore, it could be argued that the debate on queer kinship is rather conceptual and abstract with its focus on normativity/antinormativity (Wiegman and Wilson 2015), whereas the sphere of ordinariness (Martin I997) and everydayness, where most of the queer kinning actually happens, is neglected and marginalised in the discussion.

In the present paper we explore this unmapped territory of queer kinship studies and specifically take a closer look at the material and everyday dimensions of kinship, based on the results of our research project Families of Choice in Poland (FoCiP, 20I3-20I6), particularly its ethnographic stage. ${ }^{2}$ We will concentrate on food practices and their role in building intimate and relational bonds and ties since they are daily and 
ordinary practices, although sometimes ceremonial, and usually shared with others. In addition, food practices have been important for people from different cultures for a long time, which has been widely studied in cultural anthropology (Counihan and Van Esterik 2013), but not so much within queer studies, particularly not within queer kinship studies. Therefore, our paper aims to fill this gap and show the importance of food practices for queer kinning.

\section{Everydayness, Ordinariness, and Silent Intimacy}

In the new family studies, rooted in David Morgan's works (e.g., Morgan 20II), the process of relationality - building emotionally important relations - is based on daily, ordinary practices of kinning. Jacqui Gabb and Janet Fink (2015) argue that the quality of personal relationships must be treated as superior to the structural parameters of the family. Relating practices approach, as they call it, means that we should understand close relationships on the one hand as situated at the intersections of various political and sociocultural contexts, and on the other hand as experienced through ordinary, prosaic interactions, gestures, and practices (Gabb and Fink 20I5, 8). They point out that whereas the analysis of ordinary familial and intimate practices is postulated by the new family studies, there are in fact very few studies that implement it as an analytical tool. Gabb and Fink (2015), contrary to the paradigm of "big social theories" and the concept of lifespan milestones where one's life trajectory changes its course (e.g., marriage, childbirth, and divorce), propose to investigate more carefully ordinary moments, which are the texture of intimacy in families. In their opinion, such approach enables us to capture the dynamic development of relations, which are often shaped by ordinary daily practices, rather than milestone events.

Concerning practices of showing affection and love, Gabb and Fink (2015) propose to take a closer look into emotion work in the relationship and specifically gendered intimate exchanges. The knowledge of what a partner perceives as a gift, which will give them pleasure and satisfy their needs, to a large extent sets the practices of showing love, even if it is not a fully conscious and planned action. The kind of practices 
that are undertaken is strongly related to the social and cultural context of shaping individual identity and one's socialisation (including gender). Sometimes problems in a relationship result from a misunderstanding of what is a gift for the partners - what is treated as a "gift" for one, is not necessarily a "gift" for the other. Therefore, the knowledge of what the needs and desires of one's partner are, is of the highest value and makes even banal practices of tenderness and care into key elements of maintaining intimacy (Gabb and Fink 2015). Their research demonstrates that the spectrum of practices that can be seen as forms of showing love to a partner is almost unlimited and to the same extent, they include romantic gestures as well as prosaic and everyday gestures of care.

Gabb and Fink's conceptualisation goes in line with the way intimacy is understood by Lynn Jamieson. Jamieson (I998; 20I I) sets her theory of intimacy against the prevalent paradigm that bases intimacy and closeness in disclosing intimacy (Giddens 1993), which entails direct verbal communication and declarations of emotions, as well us confiding and confessing between the partners, and identifies love with emotional expression and talking about feelings and emotions (Cancian 1986). In her concept of silent intimacy she points out that building intimacy is not always based on verbal communication but very often shaped by wider repertoire of practices, such as providing support, sharing material goods or knowledge, spending time together, providing care, or physical displays of feelings. These practices create a sense of intimacy, but not necessarily a permanent sense of intimacy or love, as they are both dynamic feelings (Jamieson 20II, 3). Jamieson points out that the practical dimensions of care are often marginalised in the Giddens-inspired approach to intimacy, whereas in daily life actions speak louder than words, and often are far more important for the creation of a satisfying, close relationship. Jamieson postulates the necessity of empirical studies of these practices because only they can demonstrate the true nature of the experience of intimacy.

Drawing on Gabb and Fink (2015) and Jamieson (1998), we believe that when discussing intimate kinning practices especially, we should be more attentive to ordinary practices of daily life. In this article we 
concentrate on feeding work as kin work in queer families and take a closer look at practices connected to food. We believe that analysis of food-related practices in queer families might open up a new perspective on building intimacies and relations with important others (particularly families of origin) that has not been taken into deeper consideration in queer kinship studies so far.

\section{Feeding Work As Kin Work}

Food has been in the centre of interests for cultural anthropologists for many years, as a human activity that plays an important role in community building. Therefore, it does not come as a surprise that food as a theme reappears in many classic anthropologist's work, starting from the famous culinary triangle by Claude Levi-Strauss (1997), and articles by Margaret Mead (1943) and Mary Douglas (1972). In reflexions on the importance of food, the role of feminism and gender studies must be underlined, because these disciplines has paid a particular attention to the "invisible" role of women as food makers (DeVault I994; Counihan and Kaplan 1998; Allison 2007). As noticed by Carole Counihan and Penny Van Esterik in the co-edited volume, Food and Culture: A Reader (2013), food is such an important subject of research because it combines many spheres - body and soul, otherness and familiarity, public and private, material and symbolic. Corporal/carnal aspects of food are also analysed within anthropology of daily life (Certeau et al. I998), sociology of life-styles (Bourdieu and Bennett 1986), and sexuality studies (Counihan and Kaplan 1998). The most important text for anthropologists' research on eating practices of gay and lesbian people in the context of queer family life, is an article by Christopher Carrington, "Feeding Lesbigay Families" (2008), and part of his book on food practices of gay and lesbian families, No Place Like Home: Domesticity and Family Life among Lesbian and Gay Relationships (1999). ${ }^{3}$

Works on food practices constitute a large part of kinship studies, particularly those regarding household-building processes (Carsten I995; 2004; Haukanes 2008; Tuomainen 2014). Whereas classic kinship studies focus on the connection between household and political/ 
public sphere, feminist perspectives overcome this tendency and allow us to look at kinship from the bottom-up angle. This type of kinship studies stands in opposition to the structural or functional framework, interested in forms and structures of kinship, and focuses instead on the processes by which kin or familial bonds are built and sustained. Janet Carsten (2004) underlines, for instance, the role of the home in construing kinship. According to her, what people do in the private sphere, builds kin ties. Thus, kinship is created through mutual meals, feeding the ones close to you, and by sharing a common household. According to her and other anthropologists, kinship is built through sharing the same food (preparing it and consuming it together), so food becomes the substance of kinship (Carsten 1995; 2004; Counihan and Kaplan 1998; Haukanes 2008; Tuomainen 2014). Carsten argues that eating together is the most important social activity within the house. Consequently, the kitchen becomes the focal point of kin work in many cultures, and cooking and eating, and sharing the daily food are the most obvious determinants of what people who live together have in common. Carsten is revolutionary in her thinking about the substance of kinship. Whereas in classic works on kinship the focus was on sexual reproduction, and blood was considered the foundation of kinship, for Carsten (2004) kinship is created through sharing food:

The important point here is that shared meals and living in one house go together, and these two processes progressively create kinship even when those who live together are not linked by ties of sexual procreation. (Carsten 2004, 4)

Similarly, Counihan and Steven Kaplan (1998) notice that through sharing food and drink, closeness and intimacy are built among partners, but also in the wider sense within the family, and between families and all the significant others, such as relatives and/or friends. They underline the role of eating together not only in the daily life but in such particular unique ritual moments as religious holidays (e.g., Christmas, Easter, and Hanukkah) or individual important moments (e.g., birth- 
days or name days celebrated in Poland). In this context, who from the family is host or who is invited and who is not, is particularly meaningful because the very act of invitation creates the boundaries between those who are regarded as family and those who are not.

The social function of eating together, referred in some publications as "commensality" (Fischler 20II), has been the subject of deep reflexions in many studies. They particularly demonstrate the idealisation of family meals (Persson Osowski and Mattsson Sydner 2019), and the pervasiveness of internalised food norms (Thorsted and Anving 2010). Although most of them focus on eating together (Sobal et al. 2002), some also concern other food-related practices, such as food preparing and cooking together as a way to construct familial lives (Thorsted and Anving 20IO).

Marjorie DeVault (1994) wrote a seminal work on the feeding of the family and its gendered aspects, as well as related inequalities. She did her research in heterosexual families in the USA, and noticed that despite many declarations of equal division of labour, the majority of food-related labour was in fact carried out by women. Their feed work consisted of emotional and intellectual work as well (e.g., shopping for and planning meal, knowledge about the dietary needs of all the family members, and updating knowledge about food ingredients and healthy food), and was constantly evaluated by their husbands and children. However, their feed work was also under their own panoptical control, because they internalised their own role as the main food provider in the family. Likewise, their feed work was equated with care and love both by them and by their family. Therefore, if the family did not like what they cooked, if they complained that it did not taste good or it was something else wrong with it, women might be considered bad or unloving mothers or wives. Consequently, any of their effort in food preparation was considered a display of their feelings towards the family, and self-fulfilment of their gender role. In her work, DeVault (I994) demonstrated how women's role in feeding the family is constructed, controlled, and evaluated. However, she also showed the important relationships between food and sustaining bonds and feelings within the 
family. As a result, feed work (and its gendered aspect) is in fact equated with building the family and kinwork.

While observing the daily reality of families of choice in Poland, we have distinguished many food-related practices (feeding work as a sign of love, and/or as kinwork, food as a gift sustaining broken ties both within and outside the couple, etc.), which transcend the frame of one's family and show their importance as a kin substance. In what follows, we describe the role of food practices in building intimacy and kin ties within families of choice in Poland. Moreover, we believe that food practices are important factors in queer (de)kinning processes, very often overlooked in Anglo-American queer kinship studies. Additionally, we claim that the role of feed work might be even stronger outside the West due to geo-political reasons, that is Poland, as a country without any recognition of same-sex relationships, might be a fertile ground for such forms of showing affection and kin ties that are less publicly visible and more hosted in the private sphere. We will return to this question in the last part of the article.

\section{Methodology}

This article draws on the findings of our research project Families of Choice in Poland (2013-2016), which was the first such complex study conducted in Poland. ${ }^{4}$ Our main goal with was to show the variety of family and intimate arrangements of non-heterosexual persons in Poland, and to understand the challenges they face in everyday life. The project had an interdisciplinary character and used a mix of various methods, both qualitative and quantitative. It was carried out in several ways, and was divided into six stages. During each stage, different research methods were used in order to obtain the most relevant kind of data that answered the research questions.

In the first year of the project, a critical discourse analysis (stage I) was done concerning mainstream, as well as more marginal discourses on "families of choice." During this stage in the research, some case studies were selected and then investigated more closely (stage 2). Later a quantitative survey (stage 3) was carried out on a sample of respon- 
dents ( $n=3.038$ in relationship and 2.378 singles) throughout the country with the use of a questionnaire with closed and open responses (for more information, see Mizielińska et al. 2015). Fifty-three In-DepthInterviews (IDIs) (stage 4) were carried out in the second year of the project with the help of the biographic interpretative narrative method (Wengraf 20or; Schütze n.d.), modified accordingly by the project team. Furthermore, during the second year of the research, ethnographic research was carried out in twenty-one families (nine male and twelve female households, including six families with children) living in various regions of Poland (stage 5). Each family was observed by ethnographers for thirty days to avoid the observer effect and interviewed on several occasions both together and separately (e.g., biographical interview with the couple, individual interview on family maps, couple interview about important pictures and objects, etc.). Therefore, the research material gathered during the ethnographic research, consisted of transcription of interviews and fieldnotes written daily by the ethnographers in their online journals and commented on by their supervisors from the research team. In the third year of the project, twenty-two Focus-GroupInterviews (FGIs) were conducted (stage 6). During all the qualitative stages, we deployed a process of thematic coding which has its roots in the grounded theory (Charmaz 2006) and used MaxQDA software to facilitate the whole process. The coding tree was modified for each part of the research, and we also used in vivo coding.

For the purpose of analysis of food practices, we have used the material gathered during In-Depth-Interviews (stage 4) and ethnographic research (stage 5). However, we will also refer to the results of our survey, which sometimes provide important contextual information on families of choice living in Poland. ${ }^{5}$

\section{Results}

\section{Feeding Work As a Sign of Love and Care between Partners}

Remembering the partner's nutritional needs was often perceived in opposition to high-flying and romantic gestures, and understood as a proof of a deep commitment and care, connected to "thinking about a partner" 
(Gabb and Fink 2015). Some referred to feeding work in the context of practicing equal, though also flexible, division of household duties. It is understood as a way to be attuned to the partner's needs and current condition. Ada mentions how important it is to be sensitive to the partner's temporary inability and help her when she is tired:

We try to meet halfway, when one is tired, it is obvious that the other one makes tea and does not make a fuss about it. This is also an expression of our feelings. (Ada)

Ada's attentiveness towards her partner's needs may be understood as signifier of general tendency to a more flexible division of household labour among LGBTQ families than heterosexual ones (Mizielińska et al. 2015; Mizielińska 2017). However, this is not to say that there are no inequalities among LGBTQ families and in that case, kind gestures could also serve as a way to overcome them.

Ewelina brings up remembering the partner's favourite food products while shopping for herself. In her case, it may be an especially important way of expressing care since they live apart and run separate households.

When I know that she would like a particular meal, I prepare it for her. She knows that I like hazelnuts in chocolate and sometimes buys them for me. I know that she likes cakes. Sometimes when we make one with Marek [Ewelina's son], it is obvious that one piece is for the aunt [Edyta] and one for Magdalena [Edyta's daughter]. (Ewelina)

Likewise, for Tadeusz, anticipating the ordinary cravings of his partner and taking care of his nutritional needs are intertwined. Addressing them proves that his partner is constantly present in his mind and therefore his love for him.

If he works, I make coffee or tea. For him it is a very nice gesture. When he prepares a meal, I approach him and hug or kiss. Such simple gestures strengthen our contact, both physically and emotionally. If I am in 
a store and I see something that is in his style or something he likes to eat, I buy it for him. So, it's like thinking about another human being in different situations. (Tadeusz)

Many respondents believe that cooking for the partner or managing their diet is a good way to show affection and care. Couples sometimes talk with great nostalgia about the beginning of their relationship. In this context, they often also mention cooking as a way of attracting a potential partner. Adrian and Maksymilian remember their first homemade meals.

A: It was June and Maksymilian used to live in a student dormitory, they only shared a kitchen, and two boys who lived next door, they were away. M: Yes, they had already left for the summer.

A: And then, you invited me and prepared some food?

M: Yes, I even made a chicken salad.

A: Because he wanted to show off his culinary skills. (Adrian and Maksymilian)

Mikołaj and Julian emphasise that preparing one's favourite meal may be a way to show love on special occasions. Below they recall the moment when Julian prepared dinner for Mikołaj's birthday, an act perceived as a very heart-warming gift.

For my birthday Julian made me pork chops, fried cabbage, and baked an apple pie. I was very happy. Apart from a gift, there was this dinner there. Honestly, I remember the gift less than that meal. (Mikołaj)

Therefore, at the beginning of the relationship meals prepared by one of the partners build up a romantic atmosphere, mutual history, and bonds. Sometimes they also represent sexual connection and the first sexual contact between the lovers. Manuela and Kinga remember and cherish the memory of their first night together and their first common breakfast, a meal many people would consider more intimate than dinner. 
During the interview around objects, they showed the interviewer an eggshell from their first morning scrambled eggs, which were prepared ten years ago. They kept it in a special box together with other material traces of their relationship. The eggshell not only reminds the partners of their romantic past, but may also symbolise the beginnings of a common life, when they decided to be together and Kinga started to sleep over at Manuela's place.

When couples talk about their daily, ordinary life or later stages of their relationship food practices are also present. Later on, in the daily life of the couples cooking for their partners becomes more of an issue of ordinary practice of care. During all stages of the relationship, having a meal together presents itself as a ritual of pleasure and a desired way to spend time together. Adam, whose partner has many health problems and works manually as a factory carpenter, mentions how he cooks for his partner and loves the time they spend together over a home-cooked meal.

After such a hard day's work, I am waiting for him. To be honest, it's so nice when we are together, we eat, let's say, I make the dinner, Mariusz comes and the dinner is ready. I think that this is the coolest thing, because I feel, for example, the need to just be in this house and make the dinner. And Mariusz comes and we sit and eat together, and then we rest together in this apartment after work. (Adam)

Because of Mariusz' health problems, Adam mentions how he plans to change their diet to a more healthy and balanced one. This proves that food practices can also be a very important way to take care of partner's health. Joanna Mroczkowska (2014), who writes about the figure of mother-healer/feeder, who by cooking and preparing nutritional meals shows her care for family members, explains that this, mostly feminine, figure is of great importance in Polish society where motherhood and family are highly valued and cherished. In the context of same-sex relationships, the gender of the healer is different but the sense of the practice remains the same. 
I came up with the idea that it would be nice if we eat more vegetables together, for example, and less fried things, less fast food. We will avoid this. I think that it is worth eating soup, which is healthier than pork chops coated in unknown fat and breadcrumbs. (Adam)

Many couples also refer to food by describing themselves as foodies. However, this does not necessarily mean that both partners cook. Sometimes only one of the partner's ability and passion for cooking becomes the way to describe the relationship's identity. Like in Ela and Ala's case, where Ela perceives it as a common identity and hobby even though it is Ala who cooks, which may signify that foodie culture is not gender neutral and indifferent to inequalities among partners inhabiting different roles in the relationship (Cairns et al. 20Io). Therefore, in this case Ala's passion and ability to cook is not only a practice of care, but also a builder of the relationship's foodie identity.

We like to eat. Ala cooks well, a large part of our life revolves around food and cooking. Well, because it is also a family thing, we can do something together. (Ela)

It also goes in line with her role as a caregiver and stay-at-home mother, and Ela's role as a breadwinner.

Many couples not only declare themselves as foodies, but they also practice a "foodie lifestyle" (Johnston and Baumann 2014) by paying special attention to the way they eat their daily meals. For them, common preparation of meals and processing meals are kinning practices that build up intimacy and closeness between the partners. For Klaudiusz and Patryk the hobby of cooking together became a passion shared equally and in a flexible way during the course of their relationship, depending on their current health and work status. Since Patryk recently became chronically ill and disabled, they stopped cooking for friends but still cook together. However, now their diet is more attuned to Patryk's health needs. They cherish this passion also because it is their only common interest, since they do not have the same taste for other 
activities and things such as movies or music. The couple describes in details how they discovered together how to bake bread, and how now the priority of the couple is to take care of Patryk's diet.

K: We bake bread, try different recipes. There was a time when we cooked more together, tried new cool things. Later...

P: I started working.

K: Yes, he also had great ideas for meals and he cooked well [...], we loved Master Chef and raved about it.

P: Now we still like cooking.

$\mathrm{K}$ : Yes, but we do it less often.

P: Because I come home after 4 p.m. and you cook all the time.

$\mathrm{K}$ : And you do not have so many new ideas anymore, we used to invent so many meals back then.

P: We do it on weekends, besides I am on my diet.

$\mathrm{K}$ : Yes, the diet, we have to eat certain things, wholegrain and stuff.

P: Yes, the diet limits us, but on weekends when we have the time, we cook. (Klaudiusz and Patryk)

In case of Ilona and Maja, preparing food together is also a builder of family intimacy. They prepare pickles together and they chose a jar of pickles as an important object during the interview about photos and objects.

I: Pickles, the only tangible evidence and symbol for me of my commitment to how we cook together sometimes. Or, we just make preserves and especially how we bake cakes. And you like baking cakes more. This is a very important thing for me.

$\mathrm{R}: \mathrm{Oh}$, in that sense?

I: I just don't know, but... you need to wait for them to be ready. A few months or even longer, by now we've done a lot of preserves.

M: Well, it is our thing. We've done a lot already this year, so...

I: I don't know, it's... it's a symbol. We'll eat them or give them away, we'll make new ones next year, I think. It will continue. (Maja and Ilona) 
The most important thing here is the joint process of making the pickles, not only the actual product of it, and the common effort put in the process. Especially as there was a long crisis in their relationship once, and they were frequently on the verge of splitting up, preparing pickles together (which would be eaten after a few months) can symbolise the durability of their relationship. In their case making preserves was not an everyday activity, it involved both women, in contrast to the preparation of ordinary meals, which only one of them cooked (Maja). They also gave away some of the preserves and in this way they expressed their love and care for their families of origin and for their friends. They wanted to share their homemade products, as they are much healthier than the ones bought at supermarkets.

It is worth mentioning that in food studies, most of the scholarship focuses on practices of eating together with less attention paid to the practices of preparing meals together. It can be argued that for LGBTQ relationships, preparing food and eating together are important for two main reasons. First, it may be connected to the perception of public space, often perceived as hostile, and of private space, often considered a safe haven (Browne and Ferreira 2015). Whereas public space is the place where LGBTQ partners typically meet (however with the rise of online hook up websites and apps, the picture becomes more complex), private space is the place where they get to know each other more closely and might show affection without risking their safety. Home has proven to be a "site of identity formation and mutual support" for many LGBTQ people (Elwood 2000, I7) and as Andrew Gorman-Murray (2007, 232) argued, it "can be understood as site of privacy, identity and heart, but not necessarily in (hetero)normative way." Performing food practices means building up a mutual notion of home and its actual space, which may strengthen their intimate bonds and relationship. Secondly, as we have mentioned, in their very core food practises are connected to the notion of family and considered means of sustaining it. Therefore, performing them may also mean taking the relationship to a different, more advanced level. Food practices enable people to show affection non-discursively, to prove commitment and love without necessarily naming it. 


\section{Food Practices and Relations with Families of Origin}

Practices connected with food (preparing/cooking, buying, giving away, feeding, etc.) are not merely means of strengthening the bonds between partners, but also with significant others such as friends or families of origin. Therefore, eating and drinking together can be perceived as a way of building closeness and bonds between both partners and their families of origin, who often do not accept or support the same-sex relationships of their relatives (Mizielińska et al. 2015; Mizielińska 2017). Sometimes, the exchange of food remains their only means to express love and care and/or to re-establish the broken ties.

Eating and drinking together, sharing the same food at the same table is a way to strengthen the bonds, particularly during such important occasions as Easter or Christmas, which in Polish Catholic culture are perceived as particularly kinning moments, celebrated festively. Food plays an important role in creating the atmosphere of closeness and welcoming. Sidney Mintz and Christine Du Bois (2002) notice the importance of festive food in marking boundaries (both on the level of relations and symbolically) between one's own group and the Other. In this context, invitation to such an important familial gathering might be perceived as a litmus paper of attitudes towards families of choice, shown by their closest relatives, and the decision who is invited and who is excluded is of a great importance. In our survey, made during the quantitative part of the research, we asked questions about being invited together to familial gatherings. The results showed that $53,2 \%$ of our respondents were not invited as a couple to any familial gatherings (Mizielińska et al. 2015). In the qualitative parts (biographical interviews and ethnographic), our research participants very often declared that being invited together by families of origin is a proof of their real acceptance and normal treatment of their relationship. In their narratives they often recall the first time they were invited together as a way of passage from being outside the family to being included in its circle; but also from going from not being recognised as a family (or as a significant relationship) to finally getting that recognition (Mizielińska 2017; Mizielińska and Stasińska 2018). 
It is also clear from our ethnographic material that during familial holidays where food is shared at the same table, families of origin manifest their acceptance or hostility towards its non-heterosexual members. Many participants described how they felt torn and sad when they could not spend the Christmas or Easter holiday together with their partners and their families of origin

It was a big problem for me that you were going away from me to your parents for Christmas and you did not spend it with me. And I couldn't go with you. (Klaudiusz)

On the other hand, moments of being invited together are recalled as particularly important. Irena describes her first meeting with her partner Dominika's mother during Christmas. She felt included in the family and very welcomed. The importance of this meeting was underlined through a special table arrangements and the food that was served. The way Dominika's mother chose to celebrate their relationship, her kinning gestures, touched Irena deeply, and it is particularly striking when compared to Irena's parents' refusal to eat at the same table as the couple during important familial gatherings, such as Irena's daughter's first communion. They never invited the couple together, either.

I met Dominika's mother when she invited me for Christmas. She served roasted pork and it was great. She moved the table to the middle of the room because she does not have a dining room and apparently it was not typical, but intended to celebrate our meeting. (Irena)

Not only do same-sex couples count on being invited, but they also invite their families of origin themselves, either because they want to be accepted (by those who do not invite them) or to pay back for the received invitations (reciprocity rule, see Mauss 20I6). Those invitations (and their acceptance) or refusal also signify closeness and a way to build connections, sometimes against all odds. In some cases, families of origin are afraid of even entering the house of their non-heterosexual rela- 
tives (this could be named as "taboo of non-heterosexual home"). For instance, Teodor's parents, who are very Catholic, stopped visiting him after Marcel moved in with him, they do not accept invitations from the couple and they do not invite them to their own house, either.

I suggested that I would organise my name day at our house and I started to invite my family. It turned out that my parents did not want to come and only my sister came. Then we met my parents because they invited us to a restaurant and they started to apologise, but also to explain that they have to keep their doctrinal integrity. (Teodor)

The way families celebrate Christmas, Easter, and other important occasions in their lives is also a mean to distinguish one's own family or to build a hierarchy between families. Consequently, what is eaten and how, becomes a signifier of class distinction between partners and their families of origin. For instance, in the working-class family of Kinga and Manuela, who raise Manuela's biological son Dariusz together, Manuela often organises Christmas or Easter dinners for Kinga's mother, which is a way to distinguish her (and her family of origin's) way to celebrate those occasions from theirs.

And during this Christmas Eve, Kinga stayed here with her mum. I prepared something although she said: "Do not make anything. Mum won't eat, maybe some herrings." They simply did not eat anything during their Christmas Eve's before, they did not even have a Christmas waffle. (Manuela)

Kinga's family of origin is depicted as worse because it does not organise a festive Christmas. But the lack of "Christmas waffle" or "some herrings" in Manuela's narration does not only mark the lower social status of Kinga's family, but it is also a proof of breaking kin ties, lack of kinning practices, etcetera. Manuela does not take into account the fact that Kinga's family might not be able to afford festive meals. She reads their poor celebrations as an anti-familial behaviour. 
On the other hand, Mateusz talked about "familial moment" by which he meant eating together as a familial activity. According to him, it is something one inherits (or not) from one's own family of origin. Similarly to Manuela and Kinga, in his relationship (with Jarek), one can observe the completely different life-styles of both families of origin. Whereas Jarek comes from an upper-middle-class family and celebrates “familial moments," Mateusz' family, low middle class, does not.

In Jarek's family, when they sit down to have dinner, before they start, they praise the food and the cook. In my family, when we eat the TV is on. There is no culture of spending time together, celebrating meals; there are no familial moments. (Mateusz)

Consequently, celebrating meals and micro-practices connected to this activity can be perceived as important factors of kinning and de-kinning practices. They can also distinguish familial (class) status and/or their aspirations. Celebrating meals and spending time together at the same table is the domain of middle and higher middle classes, who can afford to spend more time on preparing food, which one should savour and not only satisfy one's hunger with (Bourdieu and Bennett I986).

Food might be shared, not only by sitting at the same table, it can also be given away and reach those who are not present, but still considered important. This way, food might work as a gift in a very similar way as described in the classic work by Marcel Mauss (2016), that is the act of giving (food) creates a special bond between the giver and the recipient. Not only do they share the same substance (food), but this substance also circulates between them and makes the kin bonds evolve. The recipient feels an obligation to reciprocate; s/he is bound up by the gift and her/ his debt must be repaid in the future. It might be returned in the form of food or any other gift (e.g., invitation to spend some time together).

Perceived this way, to give food to significant others or to receive it from them, might be seen as a way of building bridges and bonds beyond divisions, smoothing disagreements, etcetera. As with any gift, when food is given, the recipient feels obliged to pay it back and this 
way, sometimes the broken communications between families of choice and families of origin might be re-built, improved, or simply continued. A good example of this kind of practice is the already mentioned family of Irena and Dominika, who together raise Gabrysia (Irena's biological daughter from her previous, heterosexual marriage). Irena's parents and other close relatives, who live in the countryside, do not accept her relationships with Dominika and her role as the co-parent. They also threatened the couple that they would not be present at important familial celebrations such as Gabrysia's first communion or her birthday if Dominika attended them. Finally, they did participate, but did not speak to them, even refused to shake hands with Dominika when they met and they sat at a different table. Because of all this, Irena has very distant and infrequent contact with them.

However, whenever Gabrysia visits them at their country house, the grandparents give her homemade products or homegrown vegetables and fruits. They are evidently aware that she is not the only beneficiary of their generosity. In this hidden way, they might express their care (if not for Dominika, then at least for their daughter) because they want them to eat healthy country grown/made food. Their act of giving might also be seen as a way to help the family materially, as they live in a rather precarious situation - Irena does not work, Gabrysia's father does not pay her child support, and Dominika is the sole provider in the family even though she works on an unsecured contract. Therefore, the offered food helps the family make ends meet. Moreover, sometimes preparing food creates the only moment when both sides of the family can symbolically meet like in the following example:

During the ethnographic research, Irena's birthday-party was thrown. On this occasion, Irena prepared sushi and there was a birthday cake prepared partly by Irena's grandmother (the sponge cake brought from the countryside), and partly by Dominika (the cream). It became a subject of a joke because in real life they could never make it together. (Ethnographer's report) 
In families of choice, who have a good relation with their families of origin, the gift of food is an ordinary signal of their acceptance and support. It might also signify the will to strengthen the familial bonds (e.g., when food is given frequently and/or on a daily basis) and work as a proof of love and care, for example, jars of soup or a whole meal that relieve the families of daily cooking and provide healthy, safe (homemade), and nutritious food. For instance in the family of Marzena and Bożena, who together raise four children from their previous marriages, the fact that Marzena's parents give them food is a very important source of support. Since only Bożena earns money in this family and Marzena is a stay-at-home mother, the family is literally at the edge of surviving. Consequently, the food received from the family of origin does not only help them to make ends meet, but also helps Marzena in her daily chores and looking after the children:

\section{During the ethnographic research Marzena and Bożena have seen Marzena's parents twice and both times they delivered to them a supply of food: meatloaf and preserves. This food was then used on many occa- sions for a long time. (Ethnographer's report)}

Jars of preserves might be a testimony of hours of work spent in kitchen by the closest relatives (usually mothers or grandmothers), but there are also gifts in the form of fresh vegetables and fruits, carefully chosen from trustworthy (and sometimes more expensive) sources. For instance, in the family of Klaudiusz and Patryk, who usually try to save money and buy products on sale in local stores, both men's mothers try to provide them with more expensive and fresh products like in the following example: "Klaudiusz buys vegetables on sale in the nearby shop and his mum buys him those fresher and more fancy ones at the market." (Ethnographer's report)

Gay couples, in particular, talk extensively about the products received from their mothers, grandmothers, and/or aunts. It might be connected with "invalidisation" of Polish men in the kitchen (Stanisz 2014), that is, female relatives are convinced that feeding their sons/ 
grandsons or nephews is a female responsibility and that they require female care, which they lack in their families. However, it is also connected to their internalisation of means of showing affection and care through feed work (DeVault 1994). As we can see from the example below, men are more than happy to benefit from this conviction, which Piotr and Ryszard's metaphor "harvest," in the following quotation, captures so sharply. Female relatives of both men manifest their feelings and support by giving them food, and Ryszard describes visits at their families of origin as follow: "When we visit Piotr's mother we collect harvest [smiles] - preserves." (Ryszard)

Sometimes, food exchange has a mutual, daily, and more ordinary character. An interesting example of this kind is the family food practices observed in the gay couple Denis and Dariusz, who are supported by Denis' family of origin. The best illustration of their familial codependency and closeness is the fact that they live in a flat situated on the first floor of Denis' parents' house, but with a separate entrance. They were invited to move in when they decided to live together. In their daily coexistence and interdependence, we can observe how the rule of reciprocity works in practice. Sometimes Denis or his mother brings food prepared by her, and at other times, Denis cooks for his mum:

Meals are generally prepared by Denis, but it happens so that he brings them from his mother. Often there is a meal exchange between both families - Denis also cooks for his mother because his father is a meat eater so mum cooks for him, sometimes his mum brings them something. (Ethnographer's report)

Although the main actors of this food exchange are Denis and his mother they represent two families, two social groups, like in the classic exchange of gifts (Mauss 20r6). It is also worth noticing another exchange of goods, for instance Dariusz helps Denis' parents solving computer problems and/or write official letters whenever they need it. The above example shows very clearly how daily observation of ordinary family practices (such as feed work) might shed a new light on relation- 
ships between families of choice and their families of origin, which in their daily life are rather codependant and not oppositional entities like in Weston's (1997) seminal book.

\section{Why Are Food Practices Important for LGBTQ+ People in Poland?}

Physical closeness and verbal declarations are stereotypically perceived as the most common ways of showing love for one's partner and building intimacy. However, informants in our study paid a special attention to the daily practices of care for the partner, as an equally important way to show their love, and sometimes as an alternative to declarations of love or physical closeness. Furthermore, the study shows that such practices are also of crucial value for the contact with families of origin.

We believe that food practices can be understood as particularly essential for Polish queer families for two main reasons. First, in Poland, the law discriminates against families of choice and they cannot fully and freely implement all practices of care. For example, taking a day off from work to look after a sick partner is often impossible because social homophobia makes it difficult to reveal the nature of the intimate relationship in the workplace (only $30 \%$ of people in a same-sex relationship had "come out" in the workplace, according to our survey results, Mizielińska et al. 2015). In addition, in Poland same-sex couples cannot be registered and recognised by law, therefore, partners are not entitled to sick leaves or guardianship allowance. Consequently, when they want to take care of an ill partner they have to take a holiday leave. It also means that the ability to take care of an ill partner is not dependent on the law, but on workplace conditions, regarding both the nature of the employment contract, and whether the occupational situation is stable and the relationship with the management positive. Therefore, to show their commitment, care, and love for the partner, non-heterosexual people may use different practices of care, less visible to the outside world but meaningful within the relationship, usually exercised within the four walls of one's home, such as those connected to feeding work. 
Secondly, Polish society has strong peasant roots and food sharing in peasant cultures has always been a common way to build up community and strengthen individual and familial bonds. Justyna Straczuk (2004), who did her ethnographic observation in the borderland between Poland and Belarus, underlines the integrating and community building role of food that transgresses one's household:

In local peasant communities family-neighbourhood relationships have never had an individual character - they bond together not as individuals but rather members of particular families, which were seen through their clan belongingness [...]. Shared food was an evident display of these relationships but also a way for their creation or renewal. (Straczuk 2004, 192)

Straczuk refers to the Mauss' (2016) work on gift exchange and other classic works, such as Bronisław Malinowski (198I) on Kula. Gift exchange has always been based on the reciprocity rule and if one breaks it, there are severe consequences - this act might be treated as a sign of animosity or aversion, and might result in exclusion or a serious conflict. Consequently, one cannot refuse to take part in food sharing because of the risk of breaking ties and the danger of exclusion to follow. Straczuk's (2004) conclusions regarding peasant culture might be, in our opinion, extended to all acts of hosting friends and/or relatives, not only in the countryside. On the one hand, the theory of gift exchange explains why people in general invite one another for meals and why there is an unwritten script that forbids refusing such invitations. On the other hand, it shows how building one's prestige organising extravagant feasts, marks boundaries between people (us vs. other).

For all those reasons, we believe that feeding work and food sharing practices play an important role in Polish society. Therefore, it should not come as a surprise that non-heterosexual couples underlined its special value. It became visible in the daily ethnographic observations, particularly during the interviews about photos and objects when couples chose items connected with food, almost as often as engagement 
rings or gifts. The importance of food was expressed in various ways. Some perceived taking care of the nutritional needs of the partner as an expression of love and care, or considered it important for the relationship to share meals at home at the same table. Others stressed that they cook and process food together and see it as an important way to build their relationship's intimacy. Finally, many couples described how food-related practices are a means that improve or sustain the often difficult relations with their families of origin. Most commonly, these three types of practices were intertwined and together they created and strengthened relationships within the family.

\section{Conclusions}

As we have shown, food-related practices were very important for most of families who took part in our research. They stressed the role of sharing the same food at the same table, and they consider eating a familial activity, which strengthens bonds and ties between partners, but also between the couple and their significant others. Therefore, their understanding of sharing food substance might be read as convergent with Carsten's (1995; 2004) processual understanding of kinship. However, the function of food went beyond its consumption and also embraced all activities related to the process of preparation, for instance meal planning, monitoring supplies, cooking together, making preserves, participation in other kitchen activities, exchange of food, remembering the partner's cravings and/or family member's taste in food, etcetera.

The daily reality of a relationship's life revolved around casual meals, jointly prepared and eaten together, and daily remembering each other's needs. All of the small gestures, often silent (Jamieson I998), but filled with a sincere need to show care and love (DeVault 1994), were very often much more appreciated than verbal declarations of love or some high-flying romantic acts of love. Efforts put into preparing food for the family might consequently be treated as a proof of love the same way any heroic and romantic gestures are. Food-related practices were also a way to ensure the family's health (Mroczkowska 2014) and security; which is why our respondents put a lot of effort into the considerations of their 
partner's diet, taking care to get healthy and fresh ingredients, attempting to buy local products, preparing their own preserves, etcetera.

Eating together sometimes had a festive character, for example to celebrate birthdays, Christmas, or any other important holiday. Then, it served as a way to distinguish between those who belong to the family, and those who do not (Mintz and Du Bois 2002; Straczuk 2004; Counihan and Van Esterik 2013). Families of origin, who do not accept the same-sex relationship of its members, express their negative attitude by not inviting the partner to family celebrations, or by not coming to their home, whereas those who support their relationship invite them together and accept their invitations in exchange. The way to express their affection (and support) was often through offering special meals and/or a particular arrangement of the table. Food was also treated as a subject of exchange (Mauss 20I6) through which broken ties between partners or with families of origin might sometimes be improved.

There is a common Polish saying "through the stomach to the heart," which we use as a title for this article. Why do we believe it is important to look at food-related practices in the context of queer kinship and family making? Maybe, just because they can easily be overlooked and ignored. Within the dominant theories and discussions on intimacy those practices fit neither the popular discourse still upholding romantic vision of love, nor scholarship where it is claimed that we witness the end of it (Hochschild 20I3; Illouz 2013), and/or calling for cherishing disclosing intimacy instead (Giddens 1993). Within the discussion on sexual normativity in queer theory, they do not fit into the polarised understanding of what is, or is not, queer and hetero/homonormative (Wiegman and Wilson 2015). Weston's (1997) famous opposition between families of choice and families of origin also does not leave room for a truer understanding of practices of care such as feeding work that happen between the parties despite the declared acceptance, or the lack of it, for the LGBTQ+ relationships of their members.

However, by noticing these small gestures that might signify care and affection, we do not want to say that LGBTQ people are loved and included by their families of origin, or that there is no need for build- 
ing intimacy or family making by other means, such as straightforward communication, but rather that there is a whole scope of non-discursive practices that are easily overlooked, especially if we base our research only on declarations of the informants, and not on observation of their daily life. As we have already said, the picture of mutual relationships is a complex one and there is a need for further and more profound investigations, because sometimes stomach can say more than the heart would dare to admit.

JOANNA MIZIELIŃSKa holds DSs (habilitation) in Sociology, University of Warsaw and a $\mathrm{PhD}$ in Women's Philosophy, Institute of Philosophy and Sociology of the Polish Academy of Sciences. She currently works as an Associate Professor at the Institute of Psychology of the Polish Academy of Sciences. Her interests concentrate on queer theory and sociology of gender, sexuality, and families. Her past research centred on the politics of translation of Anglo-American queer theoretical approaches/concepts into other geo-political contexts and the question of exclusion. Her current research focuses on queer kinship and queer families. Recently she was a Principal Investigator of the project Families of Choice in Poland (2013-2016), which was the first multi-method project on non-heterosexual families in Poland. Currently she is a co-investigator in the research project Queer(y)ing Kinship in the Baltic Region, Södertörn University, and Doing Right(s): Innovative Tools for Professionals Working with LGBT Families, University of Verona. She is the author of Different or Ordinary?: Families of Choice in Poland (PWN 2017), Sex/Body/Sexuality (Universitas 2007), and (De)Constructions of Femininity (Universitas 2004), and coauthor of In Different Voices: Families of Choice in Poland (PWN 2017), and Families of Choice in Poland: Family Life of Non-Heterosexual Persons (IP PAN 2015). She is co-editor of De-Centring Western Sexualities: Central and Eastern European Perspective (Ashgate 20I I). Her most recent writing focuses on critical analysis of discourses on families of choice in Poland (Journal of Homosexuality 2017) and doing research on queer kinship beyond Western queer paradigms (Sexualities 2017). 
agata stasińska is a Sociologist. She holds a $\mathrm{PhD}$ in Social Sciences, University of Warsaw. She was a research officer in the project Families of Choice in Poland, at the Institute of Psychology of the Polish Academy of Sciences, were she now works as Assistant Professor. She is a graduate of the Faculty of Psychology at the University of Social Sciences and Humanities and postgraduate of Gender Studies at the University of Warsaw. She coordinated the organisation of national and international conferences, e.g., Queer Kinship and Relationships (Polish Academy of Sciences 2015). She is the author of Sociology of the Couple: Intimate Practices in Non-Heterosexual Relationships (Nomos 2018), and co-author of Families of Choice in Poland: Family Life of Non-Heterosexual Persons ( IP PAN 2015). She has coedited books, for example, Strategie Queer: Od teorii do praktyki (Difin 2012), and special issues of journals, such as InterAlia and Studia Socjologiczne, and has published several articles on the sociology of intimate and familial life and sexuality in Journal of Homosexuality, Sexualities, Studia Sociologiczne, Societas/Communitas, InterAlia, and others.

\section{REFERENCES}

Allison, Anne. 2007. "Japońskie Matki i Obento: Pudełko z Drugim Śniadaniem Jako Ideologiczny Aparat Państwa." In Gender: Perspektywa Antropologiczna, edited by Renata Hryciuk and Agnieszka Kościańska, Tom I: Organizacja społeczna:I46-7I. Warsaw: WUW.

Bourdieu, Pierre, and Tony Bennett. 1986. Distinction: A Social Critique of the Judgement of Taste. London: Routledge.

Browne, Kath, and Eduarda Ferreira. 2015. Lesbian Geographies: Gender, Place and Power. Farnham: Ashgate.

Cairns, Kate, Josée Johnston, and Shyon Baumann. 2oro. "Caring About Food: Doing Gender in the Foodie Kitchen.” Gender E' Society 24-5:59I-6I5. https://doi.org/Io.1177/0891243210383419.

Cancian, Francesca M. 1986. "The Feminization of Love.” Signs I I.4:692-709. https://doi.org/Io.1086/494272.

Carrington, Christopher. 1999. No Place Like Home: Domesticity and Family Life among Lesbian and Gay Relationships. Chicago: University of Chicago Press. 
-. 2008. "Feeding Lesbigay Families." In Food and Culture: A Reader, edited by Carole Counihan and Penny Van Esterik, 259-86. New York: Routledge.

Carsten, Janet. 1995. "The Substance of Kinship and the Heat of the Hearth: Feeding, Personhood, and Relatedness among Malays in Pulau Langkawi." American Ethnologist 22.2:223-4I.

-. 2004. After Kinship. Cambridge: Cambridge University Press.

Certeau, Michel de, Luce Giard, and Pierre Mayol. 1998. The Practice of Everyday Life: Volume 2: Living and Cooking. Minneapolis: University of Minnesota Press.

Charmaz, Kathleen C. 2006. Constructing Grounded Theory: A Practical Guide through Qualitative Analysis. London: Sage.

Counihan, Carole, and Penny Van Esterik, eds. 20r3. Food and Culture: A Reader. New York: Routledge.

Counihan, Carole, and Steven L. Kaplan. 1998. Food and Gender: Identity and Power. Amsterdam: Harwood Academic.

DeVault, Marjorie L. 1994. Feeding the Family: The Social Organization of Caring As Gendered Work. Chicago: University of Chicago Press.

Douglas, Mary. I972. “Deciphering a Meal.” Daedalus Ior.r:6I-8r.

Elwood, Sarah A. 2000. "Lesbian Living Spaces: Multiple Meanings of Home.” Journal of Lesbian Studies 4.I:I I-27. https://doi.org/IO.I300/JI55V04nor_02.

Fischler, Claude. 2or r. "Commensality, Society and Culture." Social Science Information 50.3-4:528-48. https://doi.org/IO.II77/05390I84II 4I3963.

Gabb, Jacqui, and Janet Fink. 2015. Couple Relationships in the $2 I^{s t}$ Century: Research, Policy, Practice. Houndmills: Palgrave Macmillan.

Giddens, Anthony. 1993. The Transformation of Intimacy: Sexuality, Love and Eroticism in Modern Societies. Stanford: Stanford University Press.

Gorman-Murray, Andrew. 2007. "Reconfiguring Domestic Values: Meanings of Home for Gay Men and Lesbians." Housing, Theory and Society 24.3:229-46. https://doi.org/I0.1080/I4036090701374506.

Haukanes, Haldis. 2008. "Sharing Food, Sharing Taste?: Consumption Practices, Gender Relations and Individuality in Czech Families." Anthropology of Food $\mathrm{S}_{3}$. http://aof.revues.org/r9I2.

Hochschild, Arlie Russell. 2013. The Outsourced Self: What Happens When We Pay Others to Live Our Lives for Us. New York: Picador.

Illouz, Eva. 2013. Why Love Hurts: A Sociological Explanation. New York: John Wiley. Jamieson, Lynn. 1998. Intimacy: Personal Relationships in Modern Societies. Cambridge: Polity.

-. 20 I r. "Intimacy As a Concept: Explaining Social Change in the Context of Globalisation or Another Form of Ethnocentricism?” Sociological Research Online I6.4. https://doi.org/IO.5153/sro.2497.

Johnston, Josée, and Shyon Baumann. 20r4. Foodies: Democracy and Distinction in the Gourmet Foodscape. $2^{\text {nd }}$ ed. New York: Routledge. 
Levi-Strauss, Claude. 1997. "The Culinary Triangle." In Food and Culture: A Reader, edited by Carole Counihan and Penny Van Esterik, 36-43. New York: Routledge.

Malinowski, Bronisław. 198r. Dzieta: Argonauci Zachodniego Pacyfiku: Relacje o

Poczynaniach i Przygodach Krajowców z Nowej Gwinei. Vol. 3. Warsaw: PWN.

Martin, Biddy. 1997. Femininity Played Straight: The Significance of Being Lesbian. New York: Routledge.

Mauss, Marcel. 2016. The Gift. Expanded ed. Chicago: HAU.

Mead, Margaret. 1943. "The Factor of Food Habits." Annals of the American Academy of Political and Social Science 225.r:I36-4I.

Mintz, Sidney W., and Christine M. Du Bois. 2002. "The Anthropology of Food and Eating." Annual Review of Anthropology 31.r:99-I I9.

https://doi.org/ro.1 I46/annurev.anthro.32.032702.13101r.

Mizielińska, Joanna. 2017. Odmienne Czy Zwyczajne?: Rodziny z Wyboru w Polsce. Warsaw: PWN.

Mizielińska, Joanna, Marta Abramowicz, and Agata Stasińska. 2015. Families of Choice in Poland: Family Life of Non-Heterosexual People. Warsaw: IP PAN.

Mizielińska, Joanna, and Agata Stasińska. 2018. "Beyond the Western Gaze: Families of Choice in Poland.” Sexualities 21.7:IoI-23. https://doi.org/10.1177/13634607177118508.

Morgan, David. 2or r. Rethinking Family Practices. Basingstoke: Palgrave Macmillan.

Mroczkowska, Joanna. 20I4. "Gospodyni, Matka, Uzdrowicielka: Rola Kuchni w Ksztaltowaniu Tożsamości Współczesnych Kobiet Wiejskich.” In Terytoria Smaku:

Studia z Antropologii i Socjologii Jedzenia, edited by Anna Wieczorkiewicz and Urszula Jarecka, 73-89. Warsaw: IFiS PAN.

Persson Osowski, Christine, and Ylva Mattsson Sydner. 2019. “The Family Meal As an Ideal: Children's Perceptions of Foodwork and Commensality in Everyday Life and Feasts." International Journal of Consumer Studies 43.2:178-86.

https://doi.org/ro.I I I I/ijcs.I2495.

Reczek, Corinne, and Debra Umberson. 201 2. "Gender, Health Behavior, and Intimate Relationships: Lesbian, Gay, and Straight Contexts.” Social Science E Medicine 74.Ir:I783-90. https://doi.org/Io.ror6/j.socscimed.20Ir.II.ori.

Schütze, Fritz. n.d. "Biography Analysis on the Empirical Base of Autobiographical Narratives: How to Analyse Autobiographical Narrative Interviews - Part I.” http://www.zsm.ovgu.de/zsm_media/Das+Zentrum/Forschungsprojekte/INVITE/ B2_I-p-I40.pdf (accessed July 2I, 20I7).

Sobal, Jeffery, Caron F. Bove, and Barbara S. Rauschenbach. 2002. "Commensal Careers at Entry into Marriage: Establishing Commensal Units and Managing Commensal Circles." Sociological Review 50.3:378-97. https://doi.org/ro.IIII/I467-954X.00388.

Stanisz, Agata. 2014. Rodzina Made in Poland: Antropologia Pokrewieństwa i Życia Rodzinnego. Poznań: Agata Stanisz. 
Straczuk, Justyna. 2004. "Wspólnotowe Funkcje Pożywienia, Czyli Pogranicze

Wyznaniowe Od Kuchni.” Kultura Wspótczesna 4:187-209.

Thorsted, Stine, and Terese Anving. 20ro. "Feeding Ideals and the Work of Feeding in Swedish Families: Interactions between Mothers and Children around the Dinner Table." Food Culture and Society I3.r:29-46.

Tuomainen, Helena. 2014. "Eating Alone or Together?: Commensality among Ghanaians in London." Anthropology of Food Sio. http://aof.revues.org/77 8.

Wengraf, Tom. 2001. Qualitative Research Interviewing: Biographic Narratives and SemiStructured Methods. London: Sage.

Weston, Kath. 1997. Families We Choose: Lesbians, Gays, Kinship [r991]. New York: Columbia University Press.

Wiegman, Robyn, and Elizabeth A. Wilson. 2015. "Introduction: Antinormativity's Queer Conventions.” differences 26.I:I-25.

\section{NOTES}

I. The proper English translation of this common Polish saying would be: "The way to a man's heart is through his stomach," but we used the literal translations since we wanted to omit its gender bias.

2. For more information about the project and its different stages, see familiesofchoice.pl.

3. It is worth mentioning that the topic of food practices of LGBTQpeople is mostly discussed in the particular context of their individual health-related behaviours and care for their body and appearance (e.g., Reczek and Umberson 201 2), rather than their practices and rituals related to food.

4. For more information about the project and its methodology, see familiesofchoice.pl.

5. The publication based on quantitative survey (Mizielińska et al. 2015) is available at the webpage of the project, familiesofchoice.pl.

\section{SAMMANFATTNING}

Begreppet families of choice, valda familjer, myntades för snart tre decennier sedan av Kath Weston (1997). Hon använde det för att beskriva situationen inom dåtidens LHBTQ-community under hiv/aidskrisen, när relationerna till ursprungsfamiljer utsattes för hårda prövningar. Ofta klarade de inte utmaningarna, men i stället blev vänskapsrelationer den främsta källan till vård och stöd för såväl de sjuka och döende, som deras partners. Sedan dess har samtida, icke-heterosexuella familjer kommit att uppfattas som deras queera efterföljare och begreppet "valda familjer" används synonymt. Fast det har skrivits mycket om ideologiska aspekter av queert släktskap, har de vardagliga, vanliga och ofta svårupptäckta släktskapspraktiker i 
tider när inget speciellt händer (som ett sjukdomsfall eller en familjekris), fortfarande inte studerats tillräckligt. Det skulle därför kunna hävdas att diskussionen om queert släktskap är tämligen begreppscentrerad och abstrakt med huvudsaklig inriktning på normativitet/antinormativitet (Wiegman och Wilson 2015), medan sfären av vanlighet och vardaglighet, där det mesta av queera släktskapande faktiskt sker, förbises och marginaliseras i diskussioner om queert släktskap.

I denna artikel undersöker vi denna outforskade sida av queert släktskap och uppmärksammar i synnerhet släktskapets materiella och vardagliga dimensioner. För att göra detta, använder vi data som samlades in i den etnografiska forskning som bedrevs inom ramen för undersökningen Families of Choice in Poland (2013-2016, PI: Joanna Mizielińska). Inom detta projekt kunde vi med hjälp av trettio dagars observation och flera tematiska intervjuer med tjugoen familjer, få en detaljerad bild av släktskapande praktiker i det dagliga livet. I artikeln undersöker vi praktiker av "tyst intimitet" (Jamieson I998), med inriktning på praktiker kring att dela mat inte bara mellan partners, utan även mellan dem och deras ursprungsfamiljer, vilka inte alltid till fullo accepterar och stöder deras relation. I kritisk dialog med angloamerikansk forskning om queert släktskap, vilken bygger på och utvecklar Westons klassiska arbete, vill vi visa att om blicken flyttas från antinormativitet till det vanliga (Martin 1997) och vardagliga i queert släktskap, kan det inte bara medföra en utveckling av fältet, utan även hjälpa oss förstå komplexiteten i relationella liv. 